\title{
Individual growth or institutional development? Ideological perspectives on motives behind Swedish higher education teacher training
}

\author{
Charlotte Silander ${ }^{1} \cdot$ Martin Stigmar $^{2}$
}

Published online: 10 May 2018

(C) The Author(s) 2018

\begin{abstract}
What are the motives for offering or engaging in higher education teacher training courses? This question is of interest for educational developers, teachers, university managers, and policy makers in order to design courses and to meet stakeholders' expectations. Previous research has mainly focused on the impact of higher education development courses on teacher practice and student learning. Few studies have investigated the motives behind these courses. In this paper, the motives are investigated among students, teachers, university management, and the government. The study is based on national and local documents on educational development and on interviews with representatives from four Swedish universities. The results show that all stakeholder groups are in favour of compulsory courses but the motives differ. Students, management, and government embrace an institutional perspective on educational development, in line with a social efficiency perspective on the purposes of higher education emphasising usefulness, function, and the production of skills. University teachers, on the other hand, have a more individual-oriented view on educational development and are more oriented towards a learning-centred perspective.
\end{abstract}

Keywords Educational development - Teacher training courses · Ideologies of education

Charlotte Silander

charlotte.silander@lnu.se

Martin Stigmar

Martin.stigmar@mah.se

1 Department of Education and Learning, Linnaeus University, SE-351 95 Växjö, Sweden

2 Malmö University, 20506 Malmö, Sweden 


\section{Introduction}

University teachers are typically carefully trained in doing research; however, frequently they lack formal pedagogical training (Gosling 2009; Holt et al. 2011; The Swedish National Union of Students (SFS) 2015). One way to address the lack of pedagogical experience is to arrange teaching training courses. As the quality of higher education becomes the focus of attention in the Western world and the demand on teaching and learning increases so does the requirement of university teachers to take part in teacher training (Gibbs 2013; Havnes and Stensaker 2006). Higher education teacher training (HETT), what is also referred to as educational development, is a well-known phenomenon, and several international studies have described the arrangements of educational development programmes in universities in a number of Western universities (Chalmers et al. 2012; Gosling 2008, Trowler and Bamber 2005).

Different actors can have different purposes with higher education development courses (Amundsen and Wilson 2012, p. 91; Chalmers et al. 2012). Teachers might focus on individual development and qualifications whereas a university might seek to secure certain quality standards. The motives behind educational development courses can be placed in a societal context. Curriculum decisions and responses are loaded with values; they are conditioned by the cultural context but also by patterns of educational ideologies that are found among the individuals involved (Trowler 1998). How the role of higher education is viewed in relation to society will have consequences for course design and for how training for university teachers is planned.

Previous research on motives for teacher training is limited. Research in the area of higher education development has primarily been concerned with impact, trying to measure whether or not the courses have an effect on university teaching and on student learning. A first group of studies investigated the impact of educational development courses on academics' thinking and teaching. A number of these have shown that courses do have an impact on how teachers view teaching and learning (Gibbs and Coffey 2004; Hanbury et al. 2008). An additional number of studies have shown a connection between educational development courses and teachers adopting a student-centred approach to learning (Chalmers et al. 2012; Chalmers and Gardiner 2015; Gibbs and Coffey 2004; Ginns et al. 2008; Postareff et al. 2007). A second group of studies have tried to measure the impact on student learning. Although recognising a possible time lag for changes in teaching practices or in student learning to become evident (McAlpine et al. 2008; Sword 2011), a direct relationship between teacher development programmes and student learning outcomes has not been established (Gosling 2008; McAlpine et al. 2008; Prebble et al. 2004). Consequently, additional research is needed to investigate the motives for arranging HETT courses. By focusing on the motives, we make a contribution to the need for broader theoretical and empirical knowledge in order to better understand national policy and institutional organisation of higher education development and the design of teaching training courses. The aim is to investigate the motives of HETT courses. Four groups of stakeholders will be focused on (a) students, (b) university teachers, (c) central university management, and (d) the government. The following research questions are asked:

- What are the motives for HETT courses among students, university teachers, central university management, and the government?

- How do these motives relate to ideologies of higher education?

Higher education development activities are referred to in the literature in various ways, as faculty development, educational development, instructional development, and academic 
development (Amundsen and Wilson 2012; Gosling 2009; Stes et al. 2010). Chalmers et al. (2012) divided teaching development programmes into formal and informal programmes. Formal programmes are accredited or required, and they are offered in either intensive or extended versions (Chalmers et al. 2012, p. 11). Informal programmes include shorter workshops or seminars, online courses, or special events. In this study, the objects of investigation are formal HETT courses in Sweden, but the result is expected to be useful for the understanding of the wider international phenomenon of higher education development.

\section{Framework for the analysis}

Previous research pointed out the division between individual or institutional motives behind educational development (Amundsen and Wilson 2012; Trowler and Bamber 2005). Individual motives consider the main purpose of teaching training courses to be engagement of faculty members in a process of personal reflection on education in order to provide changes in individual teachers' conceptions of teaching and learning, linking this to teaching practices. Higher education development is then viewed as something personal and voluntary.

Institutional motives, on the other hand, are more related to strategic planning and quality management (D’Andrea and Gosling 2005; Havnes and Stensaker 2006). The main focus is not on the teacher but on change of the whole organisation. Development initiatives are often top-down and take place in response to an institutional or national agenda (Amundsen and Wilson 2012). Impact on organisational change and improved educational quality is obviously facilitated if the courses are made compulsory (Havnes and Stensaker 2006; Trowler and Bamber 2005).

According to both perspectives, the underlying assumption is that the HETT courses will have an effect on an individual teacher who will contribute to changing the organisation and raising the quality. The idea of automatic change is, however, stronger in the institutional perspective and has been criticised by scholars who argue that the link between development of teaching and institutional change is not automatic but needs further investigation (Gibbs and Coffey 2004; Trowler and Bamber 2005).

To move beyond the division between individual and institutional motives, we turn to ideologies of education. These ideologies serve to build a bridge between the societal context and the motives for education. The perceived role of education and knowledge in society will influence the type of education offered. Ideology can be understood as a framework of values and beliefs about social arrangements and distribution of resources that provides a guide and a justification for behaviour (Hartley 1983, p. 26). Does education fulfil a higher purpose of liberating the human mind and making the world a better place to live in, or is education primarily about producing economic growth and welfare? Acknowledging that the economic, social, and individual motives for education are related and that the needs of the economy and the concerns with social justice and personal development are complex and interconnected as employment often contributes to personal fulfilment, it is still possible to detect distinct ideas about the main purpose of education. The literature provides several different presentations of educational ideologies (See Burgess 1977; Fanghanel 2012; Schiro 2008; Trowler 1998; Young 2007). Here a categorisation inspired by Trowler (1998) and Schiro (2008) distinguishes between the traditional ideology, the social efficiency ideology, the learner-centred ideology, and the social reconstruction ideology. The categories presented are ideal types that serve to help to understand the beliefs and values held about the role of universities and of 
academics as teachers. They are useful for showing differences between phenomena or characterising traits with the purpose to clarify important features and facilitate comparison (Esaiasson et al. 2007).

An important distinction is made between concerning whether education has a value of its own or whether it serves a function (Schiro 2008). The perspective that education has personal, social, and cultural benefits that supersede economic benefits comes in different forms. The Humboldt tradition gives education a value of its own, according to the view that knowledge has an intrinsic value (Hirst 1974). A functional way is to view education as base for liberation and empowerment and therefore of benefit for the individual (Freire 1972). The content can focus on the discipline and propositional knowledge (knowledge of the facts) or prescribing general transferable skills (Trowler 1998). Content or function is also related to how knowledge is viewed and from where it derives its authority. Does knowledge have a value of its own or is it to serve a function (Schiro 2008)?

According to the traditional perspective, the virtue of education exists for its own sake, cultural and disciplinary heritage is valued, and advancement in the field is emphasised in order to find new knowledge and produce new experts (Schiro 2008; Trowler 1998). In line with the Humboldt ideal of Bildung, education should not provide professional skills but rather allow students to build individual character by choosing their own ways (Michelsen 2010). Students learn out of curiosity and interest in a subject (Fanghanel 2012; Troiano and Elias 2014). Knowledge is viewed as objective and derives its authority from the discipline where the truth has been verified through scientific methods (Schiro 2008 , p. 176). Focus is on content, learning means transmitting knowledge to a student who lacks it, and teachers are authorities who are to pass over the knowledge of a discipline to students. Learning is unique for the discipline, which makes the traditionalists worried that the discipline will vanish with increased focus on transferable skills (Trowler 1998). The approach is generally characterised by elitism (Trowler 1998). For a traditionalist, higher education development has individual motives in line with embracing the ideal of an autonomous university and the independent professional teacher (Burgess 1977) where a teacher should be given the possibility to develop in his or her role by exploring the didactics relevant for the discipline. Courses should be theoretically oriented and voluntary.

The social efficiency ideology places education in relation to its functions and views knowledge as a way to build capability for action. The authority is derived from the impact it can have on society by providing individuals with the skills they need in order to function (Schiro 2008, p. 177). In Schiro's version, the main purpose of education is to be useful in general for a client - often the society as a whole (Schiro 2008, p. 176) — whereas Fanghanel (2012) focuses more on efficiency in economic terms. A "consumer" perspective on students (Jungblut et al. 2015) means student needs are understood as facilitating knowledge useful for employment. Proponents of the social efficiency ideology view learning as a process where behaviour is to be changed (Schiro 2008, p. 180). The objective is to prepare students to perform skills, and effectiveness is measured as student learning. A curriculum can be developed in a "scientific instrumentalist" manner, similar to the way industry produces products (Schiro 2008, p. 61). The view of propositional knowledge is utilitarian. In a social efficiency perspective, educational development should have an institutional focus with the ambition to make teachers more efficient in making students learn by introducing new teaching methods in line with a "constructive alignment approach" (Biggs and Tang 2011), new technology, and a student-centred approach. 
The learner-centred ideology is less related to society and more occupied with how learning should take place. Academic standards are viewed as of less importance and focus is more on students' benefits. The perspective is still within the Humboldt tradition of higher education (Trowler 1998) and differs from the social efficiency perspective in the way that the main objective is not vocational; instead, it wants to educate critical, independent thinkers. Disciplinary knowledge and traditions are considered to be of less importance (Trowler 1998). Students' freedom of choice and personal development is more important than propositional knowledge. Teaching is considered successful if it makes individuals grow (Schiro 2008, p. 103). The learning-centred approach rejects elitism and favours mass access to higher education. The approach is concerned with social inequality and believes in education as a way to help disadvantaged groups as much as possible, but without intentions to reconstruct society. Educational development courses should have an individual focus, making teachers understand how students learn and how to teach critical thinking. A learning-centred approach in educational development would focus on methods of improving students' critical thinking as well as issues of equality and democracy in higher education.

The social reconstructionist ideology of education also has a functional perspective, but instead of economic growth, the focus is on social, personal, and human transformation of individuals or society (Schiro 2008). The authority of knowledge and intent of teaching derives from its potential to shape a future good society. Education should serve as a basis for personal growth and for development of personal capabilities that can help to promote equality (Freire 1972). Liberation and empowerment can encourage action against political oppression and question the existing society; education is for the benefit of individuals, but not necessarily for economic gains.

Educational development in line with the social reconstruction perspective could have an individual or institutional approach and focus on education as a basis for equality and democracy and how teachers can encourage students' critical thinking and moral responsibilities. Examples would be focusing on issues such as gender equality, equality of education, and sustainable development.

Based on Schiro (2008) and Trowler (1998), Table 1 below sums up the four perspectives discussed and their stand on motives, main objectives of higher education, view on knowledge, and perception on teaching and learning.

\section{Method and material}

A stakeholder model of investigation is used, where the perceptions of actors associated with a programme are investigated (Guba and Lincoln 1989). In order to understand different stakeholders' ideological positions, documents and interviews will be analysed based on motives behind educational development, the objective of higher education, and the view on teaching and learning. Data were collected on three levels (government, central university management, and individual). Previous studies on educational development at large, full-scale universities (see Lindberg-Sand and Sonesson 2008; Brommesson et al. 2016) need to be complemented with investigations of newer universities that are less research oriented and more focused on undergraduate education. Four universities in Sweden were selected for our study: Karlstad University (KU), Linnaeus University (LU), Mid Sweden University (MSU), and Örebro University (ÖU). These institutions are geographically spread in Sweden and they all have doctoral education and research, but as new universities, the main focus of their activity is related to undergraduate education. The institutions are large enough to have well- 
Table 1 Framework for analysis

\begin{tabular}{|c|c|c|c|c|}
\hline Perspectives & Traditional & Social efficiency & Learner centred & Social reconstruction \\
\hline Motives & $\begin{array}{l}\text { Individual } \\
\text { development } \\
\text { related to the } \\
\text { discipline }\end{array}$ & $\begin{array}{l}\text { Institutional-to } \\
\text { make teachers } \\
\text { efficient in } \\
\text { making student } \\
\text { learn }\end{array}$ & $\begin{array}{l}\text { Individual } \\
\text { development } \\
\text { for critical } \\
\text { thinking and } \\
\text { growth }\end{array}$ & $\begin{array}{l}\text { Individual or } \\
\text { institutional for } \\
\text { liberation and } \\
\text { empowerment }\end{array}$ \\
\hline $\begin{array}{l}\text { Main objective of } \\
\text { higher education }\end{array}$ & $\begin{array}{l}\text { To value cultural } \\
\text { and disciplinary } \\
\text { heritage } \\
\text { extends the } \\
\text { existence of the } \\
\text { discipline }\end{array}$ & $\begin{array}{l}\text { To efficiently and } \\
\text { scientifically } \\
\text { carry out a task } \\
\text { for a client. To } \\
\text { equip students } \\
\text { with skills }\end{array}$ & $\begin{array}{l}\text { To stimulate the } \\
\text { growth of } \\
\text { people and } \\
\text { fulfil personal } \\
\text { needs }\end{array}$ & $\begin{array}{l}\text { To reshape the society } \\
\text { and be a force for } \\
\text { social change }\end{array}$ \\
\hline $\begin{array}{l}\text { Knowledge-function } \\
\text { or content }\end{array}$ & $\begin{array}{l}\text { Discipline-based } \\
\text { propositional } \\
\text { knowledge } \\
\text { (content) }\end{array}$ & $\begin{array}{l}\text { Knowledge as } \\
\text { capabilities for } \\
\text { action (function) } \\
\text { and to keep up } \\
\text { society through } \\
\text { skills }\end{array}$ & $\begin{array}{l}\text { Focus on } \\
\text { personal } \\
\text { meanings of } \\
\text { knowledge } \\
\text { (content) }\end{array}$ & $\begin{array}{l}\text { Capabilities for } \\
\text { liberation and } \\
\text { empowerment } \\
\text { (function) }\end{array}$ \\
\hline $\begin{array}{l}\text { Teaching and learning } \\
\text { (discipline-based } \\
\text { propositional or } \\
\text { transferable skills) }\end{array}$ & $\begin{array}{l}\text { Teaching as } \\
\text { transmission in } \\
\text { order to } \\
\text { advance the } \\
\text { student }\end{array}$ & $\begin{array}{l}\text { Transferable skills to } \\
\text { prepare the } \\
\text { student to } \\
\text { perform }\end{array}$ & $\begin{array}{l}\text { Student } \\
\text { participation, } \\
\text { student } \\
\text { freedom of } \\
\text { choice to } \\
\text { stimulate } \\
\text { personal } \\
\text { growth }\end{array}$ & $\begin{array}{l}\text { Skills more important } \\
\text { than disciplinary } \\
\text { content to } \\
\text { acculturate the } \\
\text { student into the } \\
\text { vison of the educator }\end{array}$ \\
\hline
\end{tabular}

Source: Schiro 2008; Trowler 1998

established higher education development programmes as well as students and teachers from a variety of faculties, but they are also small enough (compared to the large research universities) to have a centralised policy on educational development instead of a number of different faculty-based policies.

Data on the governmental view of motives is collected in the form of governmental bills, propositions, and government commissions between 1990 and 2017 related to educational development and teach training. The view of the central management level is represented by documents from the Association of Swedish Higher Education (SUHF) and by internal university documents, vision statements, strategies, and annual reports related to educational development (2013-2017). Three interviews with representatives from the central university management were also conducted. The view of the university teachers was investigated by analysing statements, publications, comments on public investigations, and political columns produced by the Swedish Association of University Teachers and Researchers (SULF) and by conducting 12 interviews with university teachers. Teachers were selected to represent a variety of faculties and had all taken part in teaching training courses during the previous three years. The motives of the students were investigated on a national level by analysing documents produced by the Swedish National Union of Students (SFS) representing the collective student voice in Sweden and by analysing statements in annual reports and opinion texts from the local student union and through 12 interviews with students. The policy documents and statements provide a collective perspective held by the stakeholders. The interviews, on the other hand, primarily serve to illustrate these views and are not used as a basis for generalisation. 
In total, 27 semi-structured interviews were conducted. Interviews typically lasted for 45 minutes up to an hour, were mostly conducted via telephone, and were recorded, and written notes were taken. Both policy extracts and interview quotes were translated by the authors and spell-checked.

\section{Results}

\section{Students}

The SFS, the local student organisation, and interviewed students all want compulsory HETT courses (SFS 2013a, 2015). Motives put forward are institutional in terms of efficiency and a changing composition of the student groups. They argue that students of today have different expectations compared to previous generations. A teacher is expected to become more efficient and better at adapting to changes if he or she undergoes training that will facilitate student learning (SFS 2015, p. 6). Further, it will lead to increased quality by facilitating teachers setting of priorities, which will professionalise the university teachers (SFS 2015, p. 8) and by making wider participation possible by addressing issue related to access to education (SFS 2015, p. 24). The individual perspective on HETT courses is less expressed in the student interviews and texts. The fact that the courses can be in the interest of the teachers' will also be beneficial for the students. "A lecturer who has the right pedagogical background creates security and offers good results for the students' performance" (Student, KU).

Mandatory pedagogical courses will, according to the student organisation, give the best possible preconditions for guaranteeing that the students will learn from teaching methods based on higher education research (SFS 2015, p. 7). In this way, the students see teaching training as a way to guarantee educational quality by signalling to the higher education institutions that pedagogic training is important for quality (SFS 2015, p. 3). Mandatory courses will also contribute to a uniform level of education nationally; the existing system in Sweden, where it is up to each university to offer courses or not, is believed to "create a potentially unequal situation for students in different programmes of study. Students at some higher education institutions can be taught by teachers with higher education teacher training who are updated on the latest methods, whereas other students at another institution risk being taught by teachers who totally lack pedagogical competence" (SFS 2015, p. 3).

For the students, the mechanism between HETT courses and increased quality is studentcentred teaching and student active learning. Quality in education will be reached by giving place to a pedagogy "based on scientific knowledge instead of traditions" as mentioned in the document from the student union (SFS 2015, p. 24) where the most important part is to use a student-centred, active-learning perspective of education. "A common denominator in order to create high quality in education, in all areas, is however a student active approach to the teaching" (SFS 2013a, p. 7). The students expect that a diffusion of certain teaching and learning methods will take place and that the courses should be compulsory in order to guarantee impact.

The social efficiency ideology of education is the dominant view among the students. Education is understood as something highly functional and something that will "supply society with skilled people in order to develop society. Professions change and become more modern and then new competence is needed" (Student, KU). 
If the interviewed students expressed a somewhat simplistic and labour market-oriented perspective on the role of higher education, the student union instead incorporated the traditional Humboldtian Bildung perspective: "Bildung does not stand in contrast to usefulness, instead Bildung is useful both for us as citizens and in working life" (SFS 2013b, p. 6). A similar view is expressed in local documents suggesting that education and training should together provide a basis for active participation in society and should not only be useful for work or further research, but also for life (Örebro Student union 2014).

Knowledge is viewed, in line with the social efficiency ideology, as giving students the ability to do things: "It is about being able to contribute to society, to be a good citizen by having a higher education" (Student, LU). Knowledge derives its authority from its function. Education should be "a platform from where you can obtain educated people with high education that can move the society forward" (Student, ÖU).

The student union departs from a transmission perspective of teaching and from the traditional perspective as it emphasises active learning and student-centred learning, which is described as "a philosophy and a university culture that encourages the student to create and design knowledge, as opposed to an older tradition in which the teacher 'repeats' or passes over the knowledge of the student" (SFS 2013a, p. 10). The term pedagogy is defined in efficiency terms as when education has "a pedagogical design aiming at efficient learning" (SFS 2013a, p. 1). Hence, the students emphasise the structure of courses and the ways they are presented, rather than the content.

The student-centred perspective shows clear signs of a social efficiency approach with its focus on learning as an active process whereby the objective is to prepare students to perform certain skills. The texts and statements produced by the student union reveal a "client" perspective of education (Fanghanel 2012). The students see it as their right to receive good teaching. "When you as a student have invested time and money in training, you should be sure that whoever stands in front of you and teaches is trained in pedagogy" (political science student as cited in SFS 2015, p. 4). This quote implicates a transfer of responsibility of learning from the student to the teacher. Or as expressed by another student: "I want to get an education based on pedagogy, I do not want to struggle in order to understand everything. This is what the teacher should help me with; he will get his students to understand things" (Student, ÖU). Teacher training is here related to a shift of responsibility for the learning. Universities should provide courses in order to guarantee that teachers have the skills to fulfil this responsibility.

\section{University teachers}

Most of the interviewed university teachers and the Swedish Association of University Teachers and Researchers (SULF) are in favour of HETT courses. Teachers identified a need for basic pedagogic skills. "Mostly, you do not have any previous teaching experience when you teach at a university" (Teacher, KU). A central motive is that teachers see it as beneficial to acquire "context knowledge" about the rules and laws governing higher education: "As a teacher, it is important to know what you need to relate to, for example, higher education law and the higher education ordinance and other rules. You need an understanding for the context where you are working" (Teacher, MSU).

Individual motives seem to be in focus; in particular, new teachers voiced a need for support and a confidence boost: "higher education teacher training courses make you feel calmer and secure in the teaching situation" (Teacher, LU). Additionally, experienced teachers view the courses as an opportunity for development. A common pedagogical understanding enables 
teachers to "get a platform so that you can identify yourself as a university teacher and develop a pedagogical language and understanding of the teaching and learning discourse and communicate with other university teachers" (Teacher, MSU). A majority of the answers can be related to reflection and development of the personal role as a teacher, but there is also a wish to reach the group of teachers who are research oriented and not interested in new teaching and learning methods: "University teachers almost always lack pedagogy. Many lack interest in pedagogy; instead, their primary interest is to do research, but only few teachers only do research. There is a risk that teachers who lack knowledge in pedagogy do worse in teaching and it is therefore important that they take part in teacher training in order to get pedagogic tools" (Teacher, KU).

Those supporting compulsory courses argue that the teachers who need them the most would otherwise not attend. The institutional perspectives are also present in the view of courses as a means of quality assurance. "Good to have a known minimum level. When you come to a university you know what you can expect in whatever discipline and teachers can ensure a level of consistency" (Teacher, LU) or "... uniformity among teachers across the country and equal values are important in order to spread new and modern pedagogical ideas" (Teacher LU). On the other hand, SULF (2016) supports the individual perspective and argues that lack of quality in higher education is related to a lack of resources and cannot easily be solved with teaching training. "Whether it is research or teaching, reflection, documentation, discussion, and critical review is crucial for university students' success" (Ericson 2016).

The university teachers expressed a learning-centred perspective, influenced by the social efficiency perspective. "The main purpose is of course personal development ... but really, the most important aim is that society gets educated people who can move society forward" (Teacher, MSU). Individual learning is in focus, but this will also be beneficial for society: "It is the fundamentals of human existence. Individuals want to develop. Education is part of human development. It can be formal, emotional, or even about facts ... to become a Renaissance person, knowledgeable and interested in humanities. Education is part of human change that benefits both people and the global community" (Teacher, ÖU).

Also, the teachers view knowledge as capabilities for action. "The main purpose is both to stimulate and provide skills for knowledge acquisition and also to teach students critical thinking, of course. It is important to provide the skills that students need in working life and that are important in professional programs" (Teacher, LU). The learning-centred approach dominates the view on teaching and learning, but there are also features of both the social efficiency perspective and the traditional perspective. The idea of learning to teach is about "becoming aware of how to begin with the needs of students, to create knowledge rather than transfer knowledge ... we can generate knowledge together, teachers don't know best all the time, we can create conditions for learning together" (Teacher, MSU). This can be contrasted by a clear social efficiency perspective held by another teacher: "On a personal level, it is about getting the things that you can benefit from throughout your life. From a societal perspective, especially for Sweden, we compete with knowledge, our education must be beneficial for us to strengthen ourselves internationally and then the teachers' teaching skills are important among many others things, higher education teacher training courses are important — both for the individual but also for society (Teacher, KU). When talking about teaching and learning, one of the few examples of the traditional perspective is present as content is put in focus: "A teacher must somehow be able to convey the main content. I don't believe that the students can understand that by themselves, but it is probably more traditional ... what is the main content? After that you can push students to think for themselves and become more critical" (Teacher, 
$\mathrm{LU})$. The interviewed teachers base their view on teaching in their discipline, but there are examples of how the discipline is challenged:

"Previously, I was more of a disciplinary expert, now it has become more important to start with students' questions and interests than in my knowledge of the discipline. There is an increased tension between students versus disciplines ... there will be criticism if we do not base the teaching on the questions from the students and their pre-conditions... today there are more student views and it leads to more friction and conflict" (Teacher, ÖU).

\section{Central university management}

The central university level is in favour of compulsory HETT courses and has an institutional perspective on educational development. SUHF has pushed for HETT courses since the beginning of the century (SUHF 2000, 2017). The motives are found in the changing preconditions for teachers in higher education which put new demands on university teachers: "We wish to signal that we think that the pedagogical education of tomorrow needs to focus on the fact that the prerequisites of higher education of today are different from before" (SUHF 2000, p. 11). In later texts, references are made to the perspective of scholarship of teaching and learning (SUHF 2017, p. 4), the Bologna process that has created a need for teachers to relate to the new European curriculum (SUHF 2017, p. 14), increases administrative demands, and increases evaluation and assessment in combination with intensified educational duties as changing the preconditions for teachers' work and motivating the development of HETT (SUHF 2017, p. 15).

Higher education development and teaching training are generally viewed as a part of overall quality management (Linnaeus University 2016; Mid Sweden University 2012; Örebro University 2009). "For me it is all about quality, undergraduate education is the dominant part of what we do and to work with the part that deals with educational development is also about educational quality, it is not only about the disciplinary parts" (University director, ÖU). Educational development is argued from an efficiency perspective: "The purpose of higher education is to contribute to a knowledge society, we train students to go out to society, to workplaces but also as citizens. We equip students with a good knowledge foundation. The teacher training is a way to make the best of the time and to offer a long-term ability to relate to knowledge and explore the world critically" (University Director, ÖU).

Additionally, the interviewed managers viewed the HETT courses as a way to control quality. "We need to guarantee some form of basic level of education. This is a good way to at least try to guarantee a basic level in a way we can control" (Dean, MSU). Managers stress the need to communicate "context knowledge" about teaching in higher education. This could, for example, include knowledge about higher education law, national and local rules for examinations, national and local policies and regulations, etc.

Individual motives were expressed, for example, that "the courses should also contain opportunities for reflection on the concept of knowledge, opportunities for discussion around fundamental issues, internationalisation, research information, gender equality, etc." (SUHF 2000 , p. 5). The main motives presented were, however, institutional and related to the emergent mass university and the increased heterogeneity of the student' group following widening participation. "Students have other demands, live in a more multifaceted society where knowledge only partly reaches them via classical university education. Obviously-we believe - that a university teacher is given a different role today when almost $50 \%$ of all students register for college compared to 2-3\% earlier" (SUHF 2000, p. 11). 
Documents also refer to cut backs and turning to educational development in order to handle the lack of resources in the sector:

"It is also important to point out another background factor, namely the resource situation. For a variety of reasons, the time for the students contact with a teacher (measured, for example, per credit) has decreased significantly - over a number of years. This applies to all areas of education but is particularly evident within Social sciences and Humanities. It must be considered unlikely that any significant improvement will take place within the foreseeable future. These circumstances must also affect the higher education development and gives the familiar phrase 'From teaching to learning' an extra weight" (SUHF 2000, p. 11).

Also, central management representatives raised the issues of limited resources, stating that it is "Important to use the best educational solution ... to be able to use the time and resources we have in the best possible way" (University Director, ÖU).

The institutional perspective on educational development is combined with a social efficiency perspective on the purpose of higher education. As expressed in the quality plan of Örebro University: "Students need to develop in-depth subject knowledge, Bildung and critical education while developing practical skills and skills that are valuable in the professional world. Education should be offered with regard to both the needs of the labour market and student demand as well as the university's internal prerequisites" (Örebro University 2009, p. 3).

There are several examples of how the universities incorporate the Humboldt perspective of Bildung into the social efficiency perspective. "All education should include a Bildung perspective, enabling the students to widen their frames of reference beyond the main field of study of the degree program, and strengthening their democratic approach. Our education and contract education is important in order to be able to meet society's need for competence" (Linnaeus University 2014, p. 10).

Bildung is referred to as something that is useful for personal development and therefore also for society: "Our education and research balance values, knowing, and practical skills. Formation and a broad knowledge base, not only as a prerequisite for a successful professional life and lifelong learning, but also as a basis for each person's personal development" (Karlstad University 2015, p. 1).

University documents further reflect a view on knowledge as something that should be useful "Knowledge should be put to use; knowledge brings change. Mathematical modelling, historical processes, or technical innovations - regardless of the area in question, knowledge is important to people and society" (Karlstad University 2016, p. 3).

Examples of both propositional knowledge and transferable skills are reflected in the documents: "Students need to develop in-depth subject knowledge, education, and critical education while developing practical skills and skills that are valuable in working life" (Örebro University 2009, p. 3). Transferable skills are, however, mentioned more frequently. Linnaeus University states that they “... combine curiosity, creativity, and utility with an entrepreneurial mind-set in students and teachers; it is about developing self-confidence, creativity, and generic competencies, as well as having the courage to take risks" (Linnaeus University 2014, p. 6). Karlstad University expresses that "The university shall also offer learning opportunities to promote creativity, flexibility, diverse skills, and holistic thinking" (Karlstad University 2015, p. 7). In connection with educational development, the need to improve e-learning is mentioned (Mid Sweden University 2008, 2016; Karlstad University 2015). 


\section{Government}

The government's view on HETT courses has moved from a wish to improve the teachers' pedagogical competences and a perceived need to enhance the status of undergraduate education to a focus on efficiency and widening participation. The Swedish Government Official Report of 1992 originated from student criticism of the higher education system and argued for a need to enhance the requirements and the quality of undergraduate education; "Higher education is designed as secondary school and does not provide enough space for independent development of the individual" (Swedish Government Official Report 1992, p. 68). The social efficiency perspective appears occasionally, but is not the focus. Instead, the proposals in the report focus on the personal and individual development of the teacher as well as emphasising the teachers' own preferences about how to develop their teaching role (Swedish Government Official Report 1992, p. 315).

Between 1990 and 1999, the number of students in the Swedish higher education system nearly doubled, growing significantly faster than the number of university teachers but the government's strategy was to further increase the number of students (Swedish Government Official Report 2000; Swedish Government Bill 2001). In 2001, a bill was introduced that suggested a requirement of 10 weeks of university teaching training courses to be included in the Higher Education Act (Swedish Government Bill 2001). The government's motive was to make it possible for a larger part of the population to obtain university education:

A university with an, in many ways, not least in terms of motivation, more differentiated student group, also places greater demands on the teaching skills of teachers. The teacher must therefore increasingly reflect on how education is conducted. He or she must also be able to stage an education that allows many different ways to approach the topic in a group where there are many different motives for study, great variety of experiences and cultural diversity. This requires substantial investment in practical pedagogical training of university teachers (Swedish Government Official Report 2000, p. 89).

The motive for the introduction of HETT courses was institutional, primarily as a way to help new student groups cope with their studies. The pedagogical development of university teachers is proposed as a solution to the problem regarding students failing to finish their courses (Swedish Government Official Report 2001, p. 55): "Mass education makes the student group far more differentiated than before. [...] Our conclusion is that the university must make a strong commitment to educational development of the university teachers so they can better manage these aspects of diversity" (Swedish Government Official Report 2001, p. 90).

The Official Report of 2001 represented a clear swing towards a social efficiency-oriented perspective: "The rapidly increasing demand for people with higher education in more sectors of society and the fast expansion of higher education in Sweden has quickly and fundamentally changed both the university's social mission and the terms for the university's activities" (Swedish Government Official Report 2001, p. 64).

Compared to the earlier text, substantial attention is paid to input from labour market representatives stating that:

...working life today requires advanced skills and knowledge of specific areas, the ability to develop and renew knowledge and skills as well as the ability to identify and formulate new problems. [ ...] These abilities musts be developed in academic 
programs, and we therefore propose that the Higher Education Act be amended accordingly (Swedish Government Bill 2001, p. 30).

Knowledge is viewed as capabilities for action: “...the traditional view of higher education has been one of an institution producing and providing knowledge" (Swedish Government Bill 2001, p. 63), but the current changes and a wider commission for higher education puts focus on transferable skills:

These are the ability to identify and formulate new problems and to be able to independently develop new knowledge and skills, readiness and ability to change based on changing external conditions, the ability to work in groups, networks and projects, intercultural competence, social skills and interpersonal skills, ability to oral and written communication in Swedish and English, and the ability to manage information and communication technology tools (Swedish Government Bill 2001, p. 87).

The social efficiency perspective is also present in the teaching and learning views. The report departs from the traditionalist approach by stating that the traditional way of viewing teaching and learning is incompatible with dealing with the new and more diverse student group.

If the higher education system tends to encourage and reward a certain kind of intelligence, $[\ldots]$ there is likely a tension between the educational practices developed in a less differentiated higher education system when these are applied on an increasingly differentiated student group (Swedish Government Official Report 2000, p. 89).

Instead, the university requires something else that is more in line with the objectives that the learning-centred perspective stipulates:

It is not enough that teaching has a formal scientific content (which is usually provided in the curriculum), but high-quality learning means that students actually learn the scientific content of the course - and that it will remain in the student's mind for a long time. Such quality requirements entail a shift in perspective from teaching to student learning and question various elements of the common ways of organizing university studies, e.g. that studies are examination oriented (Swedish Government Official Report 2000, p. 100).

The quote shows the shift of focus from teaching to learning and a shift from the traditional approach to a learning-centred approach, but even more so towards the social efficiency approach because learning has to be efficient.

New student groups require many new and varied activities in a situation that is often characterized by lack of time. Therefore, the teachers face difficult priorities and need to identify activities that are indispensable for students to successfully complete their studies (Swedish Government Official Report 2001, p. 61).

In this way, HETT courses become a way to balance the lack of resources in the growing higher education sector.

The requirement of 10-week mandatory courses in educational development was removed in 2010 (Swedish Government Bill 2010), and the issue of higher education development has more or less been absent from the governmental agenda since the beginning of the century. 


\section{Discussion}

There is a strong discourse in favour of HETT courses among all the investigated stakeholders. The students, central managements, and the government fit into the category of social efficiency perspective on higher education. Teachers, on the other hand, represent a learning-centred perspective, but with features of the social efficiency perspective.

Table 2 sums up the view of the stakeholders concerning motive, main objective of higher education, view on knowledge, and view on teaching and learning. Students are in favour of compulsory courses and have an institutional perspective on higher education development. They have expressed their views that student-centred teaching facilitates and guarantees student learning as well as increases the level of quality in education. Teachers put the need for personal reflection before institutional change and courses are needed to compensate for the lack of educational experience and to provide contextual knowledge. For the university management, compulsory teaching training courses are a part of the quality management system and seen as a way to deal with limited resources, to guarantee a basic level of education, and to guarantee teachers' legal knowledge. For the government, educational development courses serve as a way to make teaching more efficient and make it possible for less motivated students to make it through the university system.

All the investigated stakeholders, except the teachers, embrace a social efficiency perspective on education with a focus on function, skills, and capabilities. Among teachers, the learning perspective on higher education is common; however, it is influenced by the social efficiency perspective. The government, students, and university management all depart from a traditional perspective to a focus on transferable skills. Knowledge should be functional and the workforce needs to become more flexible to cope with rapid changes.

Table 2 Stakeholder's positions in relation to educational ideologies

\begin{tabular}{|c|c|c|c|c|}
\hline Perspectives & Students & $\begin{array}{l}\text { University } \\
\text { teachers }\end{array}$ & Central management & Government \\
\hline Motives & $\begin{array}{l}\text { Institutional: } \\
\text { efficiency and } \\
\text { composition of the } \\
\text { student group. To } \\
\text { make teachers } \\
\text { efficient. To make } \\
\text { courses equal }\end{array}$ & $\begin{array}{l}\text { Individual: lack of } \\
\text { teaching } \\
\text { experience, } \\
\text { need for context } \\
\text { knowledge and } \\
\text { individual } \\
\text { development }\end{array}$ & $\begin{array}{l}\text { Institutional: } \\
\text { mass-university } \\
\text { and heterogeneous } \\
\text { student groups. In- } \\
\text { creasing adminis- } \\
\text { trative demands } \\
\text { and lack of re- } \\
\text { sources }\end{array}$ & $\begin{array}{l}\text { Institutional: } \\
\text { mass-university } \\
\text { and heteroge- } \\
\text { neous student } \\
\text { groups. To help } \\
\text { new students } \\
\text { through } \\
\text { university }\end{array}$ \\
\hline $\begin{array}{l}\text { Main objective of } \\
\text { higher education }\end{array}$ & $\begin{array}{l}\text { Social efficiency } \\
\text { perspective: } \\
\text { education should } \\
\text { supply society } \\
\text { with skilled people }\end{array}$ & $\begin{array}{l}\text { Learning-centred } \\
\text { perspective with } \\
\text { influences of } \\
\text { social efficiency }\end{array}$ & $\begin{array}{l}\text { Social efficiency } \\
\text { perspective, to } \\
\text { contribute to the } \\
\text { knowledge society }\end{array}$ & $\begin{array}{l}\text { Social efficiency } \\
\text { perspective, to } \\
\text { contribute to } \\
\text { society and to } \\
\text { the labour } \\
\text { market }\end{array}$ \\
\hline $\begin{array}{l}\text { Knowledge-function } \\
\text { or content }\end{array}$ & $\begin{array}{l}\text { Function: capabilities } \\
\text { for action }\end{array}$ & $\begin{array}{l}\text { Function: } \\
\text { capabilities for } \\
\text { action }\end{array}$ & $\begin{array}{l}\text { Function: capabilities } \\
\text { for action }\end{array}$ & $\begin{array}{l}\text { Function: } \\
\text { capabilities for } \\
\text { action }\end{array}$ \\
\hline $\begin{array}{l}\text { Teaching and learning } \\
\text { (discipline-based } \\
\text { propositional or } \\
\text { transferable skills) }\end{array}$ & Transferable skills & $\begin{array}{l}\text { Discipline-based } \\
\text { knowledge }\end{array}$ & $\begin{array}{l}\text { Propositional } \\
\text { knowledge and } \\
\text { transferable skills }\end{array}$ & Transferable skills \\
\hline
\end{tabular}


Students, management, and government transcend the categories and incorporate important features from the traditional Humboldt idea of education into the social efficiency perspective. The very essence of the traditional idea of Bildung, a personal development that seeks to change the whole person including their ethical standings, is, in fact, contradictive to its usefulness. In the rhetoric, though, Bildung is instead presented as useful for society and economic growth, in a similar way as education, and knowledge is valued for its functions.

\section{Conclusions}

There are three important contributions of the study that educational developers and central university managements need to consider. First, there is a strong ideology of efficiency, usefulness, and labour market orientation motivating HETT courses. This can be contrasted with the lack of mentioning of words like equity, gender equality, and sustainable development. Instead, the focus is on the regulatory parts and quality assurance in educational development. Both documents and interviews with central university managements show a lack of strategy concerning educational development; there is instead a checklist approach to teacher training. Second, the social efficiency ideology view of all stakeholders except the teachers indicates an instrumentalist view of teaching. Educational development courses, often influenced with ideas about "constructive alignment", need to avoid the risk raised by Fanghanel (2012) of turning the curriculum into a package that is predictable and limiting the possibilities for exploration and improvisation. Finally, the often present focus in the literature on the importance of "the reflective practitioner" in higher education teaching training (Trowler and Bamber 2005, p. 84; Amundsen and Wilson 2012) seems to be of less concern for the investigated stakeholders except for among teachers themselves. The diverging view of the teachers on the motives and ideology of educational development compared to the other groups needs to be kept in mind to maintain the legitimacy of the HETT courses.

Open Access This article is distributed under the terms of the Creative Commons Attribution 4.0 International License (http://creativecommons.org/licenses/by/4.0/), which permits unrestricted use, distribution, and reproduction in any medium, provided you give appropriate credit to the original author(s) and the source, provide a link to the Creative Commons license, and indicate if changes were made.

\section{References}

Amundsen, C., \& Wilson, M. (2012). Are we asking the right questions? A conceptual review of the educational development literature in higher education. Review of Educational Research, 82(1), 90-126.

Biggs, J., \& Tang, C. S.-K. (2011). Teaching for quality learning at university: what the student does. Maidenhead: Open University Press.

Brommesson, D., Erlingsson, G. Karlsson Schaffer, J., Ödalen, J, \& Fogelgren, M. (2016). Att möta den högre utbildningens utmaningar. Meeting the challenges in higher education. Institute for evaluation of Labour Market and Education Policy. Stockholm: IFAU. Retrieved from https://www.ifau. se/globalassets/pdf/se/2016/r-2016-04-att-mota-den-hogre-utbildningens-utmaningar.pdf. 2018-02-07.

Burgess, T. (1977). Education after school. London: V. Gollancz.

Chalmers, D., \& Gardiner, D. (2015). An evaluation framework for identifying the effectiveness and impact of academic teacher development programmes. Studies in Educational Evaluation, 46, 81-91.

Chalmers, D., Stoney S., Goody, A., Goerke, V., \& Gardiner, D. (2012). Measuring the effectiveness of academic professional development. In Identification and implementation of indicators and measures of effectiveness of teaching preparation programs for academics in higher education. Ref: SP101840. The University of Western Australia Curtin. https://doi.org/10.13140/RG.2.1.3882.8567. 
D’Andrea, V., \& Gosling, D. (2005). Improving teaching and learning in higher education: a whole institution approach: a whole institution approach. New York City: McGraw-Hill Education.

Ericson, M. (2016). Så förbättras undervisningen, Upsala Nya Tidning 2016-08-13. This is how teaching and learning is improved. Retrieved from https://login.ntm.eu/pren/default.aspx?sn=UNT\&meter=true\&action= completerequest \&redirect $=\mathrm{http} \% 3 \mathrm{a} \% 2 \mathrm{f} \% 2 \mathrm{fwww}$.unt.se $\% 2$ fasikt $\% 2$ fdebatt $\% 2$ fsa-forbattrasundervisningen4330125.aspx\&callback=http\%3a\%2f\%2fwww.unt.se\%2finc\%2feprencallback.aspx. 2018-02-07.

Esaiasson, P., Gilljam, M., Oscarsson, H., \& Wängnerud, L. (2007). Metodpraktikan: konsten att studera samhälle, individ och marknad. Stockholm: Norstedts Juridik AB.

Fanghanel, J. (2012). Being an academic. London: Routledge.

Freire, P. (1972). Pedagogy of the oppressed. Harmondsworth: Penguin.

Gibbs, G. (2013). Reflections on the changing nature of educational development. International Journal for Academic Development, 18(1), 4-14.

Gibbs, G., \& Coffey, M. (2004). The impact of training of university teachers on their teaching skills, their approach to teaching and the approach to learning of their students. Active Learning in Higher Education, 5(1), 87-100.

Ginns, P., Kitay, J., \& Prossner, M. (2008). Developing conceptions of teaching and the scholarship of teaching through a graduate certificate in higher education. International Journal for Academic Development, 13(3), 175-185.

Gosling, D. (2008). Educational development in the United Kingdom. Report for the heads of educational development group. London, UK: Heads of Educational Development Group (HEDG).

Gosling, D. (2009). Educational development in the UK: a complex and contradictory reality. International Journal for Academic Development, 14, 5-18.

Guba, E. G., \& Lincoln, Y. S. (1989). Fourth generation evaluation. City: Sage.

Hanbury, A., Prosser, M., \& Rickinson, M. (2008). The differential impact of UK accredited teaching development programmes on academics' approaches to teaching. Studies in Higher Education, 33(4), 469-483.

Hartley, J. (1983). Ideology and organizational behaviour. International Studies of Management and Organisation, 13(3), 24-36.

Havnes, A., \& Stensaker, B. (2006). Educational development centres: from educational to organisational development? Quality Assurance in Education, 14(1), 7-20.

Hirst, P. (1974). Knowledge and the curriculum. London: Routledge \& Kegan Paul.

Holt, D., Palmer, S., \& Challis, D. (2011). Changing perspectives: teaching and learning centres' strategic contributions to academic development in Australian higher education. International Journal for Academic Development, 1, 5-17.

Jungblut, J., Vukasovic, M., \& Stensaker, B. (2015). Student perspectives on quality in higher education. European Journal of Higher Education, 5(2), 157-180.

Karlstad University. (2015). Vision 2015 (KAU vision 2015).

Karlstad University. (2016). Årsrapport Karlstad Universitet. (Annual report of Karlstad University). Retrieved from https://www.kau.se/files/2017-02/Arsredovisning_2016_.pdf. 2018-02-07.

Lindberg-Sand, Å., \& Sonesson, A. (2008). Compulsory higher education teacher training in Sweden: development of a national standards framework based on the scholarship of teaching and learning. Tertiary Education and Management, 14(2), 123-139.

Linnaeus University. (2014). En resa in i framtiden Vision och strategi 2015-2020. A journey into the future vision and strategy 2015-2020. https://nu.se/contentassets/12983c6eef714f4994c11fa20d8f903b/a journey into the future 2015-2020.pdf.

Linnaeus University. (2016). Pedagogisk plan för Linnéuniversitetet 2015-2020. (Pedagogical plan for Linnaeus University 2015-2020). Linnéuniversitetet, Växjö. Retrieved from https://nu.se/contentassets/3744d2d7 c273477aa35ab651410af361/pedagogical-plan-2015-2020.pdf. 2018-02-07.

McAlpine, L., Oviedo, G., \& Emrick, A. (2008). Telling the second half of the story: linking academic development to student experience of learning. Assessment \& Evaluation in Higher Education, 33(6), 661-673.

Michelsen, S. (2010). Humboldt Meets Bologna. Higher Education Policy, 23(2), 151-172.

Mid Sweden University. (2008). Pedagogisk utvecklingsplan för Mittuniversitetet 2008-2011. (Plan for pedagogical development at Mid Sweden University).

Mid Sweden University. (2012). Ramverk för Mittuniversitetets kvalitetsarbete Utbildning på grundnivå, avancerad nivå och forskarnivå (Framework for quality at first, second and third cyclel). Falun: Mid Sweden University.

Mid Sweden University. (2016). Arsredovisning 2015 (Annual report 2015). Retrieved from https://medarbetarportalen.miun.se/globalassets/styrdokument/1.-ledning-och-styrning/uppfoljning/ramverkfor-miuns-kvalitetsarbete.pdf. 2018-02-07.

Örebro Student union. (2014). Strategi för Örebro studentkårs utbildningsbevakning- Verksamhetsåren 2014/ 2015 och 2015/2016 (Strategy for Örebro student union's coverage of educational matters). Örebro universitet.

Örebro University. (2009). Kvalitetsplan för Örebro universitet. Dnr: CF 10-555/2009. Quality plan for Örebro University. Örebro universitet. 
Postareff, L., Lindblom-Ylänne, S., \& Nevgi, A. (2007). The effect of pedagogical training on teaching in higher education. Teaching and Teacher Education, 23, 557-571.

Prebble, T., Margraves, H., Leach, L., Naidoo, K., Suddaby, G., \& Zepke, N. (2004). Impact of student support services and academic development programmes on student outcomes in undergraduate tertiary study: a best evidence synthesis. Wellington: Ministry of Education.

Schiro, M. (2008). Curriculum theory conflicting visions and enduring concerns. Thousand Oaks: Sage publications.

Stes, A., Min-Leliveld, M., Gijbels, D., \& Van Petegem, P. (2010). The impact of instructional development in higher education: the state-of-the-art of the research. Educational Research Review, 5(1), 25-49.

SUHF. (2000). Association of Swedish Higher Education. Högskolans lärare i 2000-talets kunskapssamhälle. Bakgrund, tankar och förslag angående lärarutbildning för högskolans lärare från SUHF:s arbetsgrupp $P U A L$. (University teachers in the 21 st Century knowledge society. Background, ideas and propositions in connection to higher education teacher training by the Association of Swedish Higher Education). Stockholm, Sweden: SUHF. Retrieved from http://www.suhf.se/MediaBinaryLoader.axd?MediaArchive FileID $=698896 \mathrm{c} 9-535 \mathrm{c}-460 \mathrm{~b}-829 \mathrm{f}-\mathrm{fd} 9 \mathrm{e} 0 \mathrm{dacf} 8 \mathrm{ea} \&$ FileName $=\mathrm{H} \% \mathrm{C} 3 \%$ B 6 gskolans $+1 \% \mathrm{C} 3 \% \mathrm{~A} 4$ rare+i+2000-talets+kunskapssamh\%C3\%A4lle_PUAL_okt+2001.pdf. 2018-02-07.

SUHF. (2017). Högskolepedagogisk utbildning: och pedägogisk meritering som grund för det akademiska lärarskapet. Higher education teacher training and pedagogical qualification as foundation for academic teaching. (The Association of Swedish Higher Education). Stockholm: SUHF.

SULF. (2016). SULF och SFS ställer krav för bättre högskolepedagogik (The Association of Swedish Higher Education and the Swedish National Union of Students make demands for improved higher education pedagogy). Universitetsläraren, July 7, 2016. http://lup.lub.lu.se/record/9da18f43-a08b-4620-ac26-d06cbbd604ea.

Swedish Government Bill. (2001). Den öppna högskolan, 2001/02:15 (The Open University). Riksdagens tryckeriexpedition. Stockholm. Retrieved from http:/www.regeringen.se/49b72b/contentassets/154f4a9b39 b2406d96c9853188619453/den-oppna-hogskolan-del-1-till-och-med-kapitel-12. 2018-02-07.

Swedish Government Bill. (2010). En akademi i tiden - ökad frihet för universitet och högskolor, 2009/10:149 (The Academy of today-increased freedom for universities and university colleges. Riksdagens tryckeriexpedition. Stockholm. Retrieved from http://www.regeringen.se/49b729/contentassets/07a972 fdbfdd43789da5a5b03dbb6f4a/en-akademi-i-tiden—okad-frihet-for-universitet-och-hogskolor-prop.200910149. 2018-02-07.

Swedish Government Official Report. (1992). Frihet, ansvar, kompetens: grundutbildningens villkor i högskolan: betänkande/av Högskoleutredningen. Freedom, responsibility, competence: conditions for the undergraduate level. Allmänna Förlaget. Utbildningsdepartementet. Stockholm.

Swedish Government Official Report. (2000). Mångfald i högskolan. Reflektioner och förslag om social och etnisk mångfald $i$ högskolan (Diversity in higher education. Reflections and proposals on social and ethnical diversity in higher education). SOU 2000:47, Utbildningsdepartementet. Stockholm. http://up.lub.lu. se/record/640515.

Swedish Government Official Report. (2001). Nya villkor för lärandet i den högre utbildningen (New conditions for learning and teaching in higher education). SOU 2001:13. Utbildningsdepartementet. Stockholm. Retrieved from http://www.regeringen.se/49b720/contentassets/1d229716edfc4c86a0cc338b94b9da7e/sou200113. 2018-02-07.

Swedish National Union of Students, SFS. (2013a). Studentens lärande $i$ centrum - Sveriges förenade studentkårer om pedagogik $i$ högskolan. (Improving teaching and learning in Swedish higher education). Globalt företagstryckeri, Stockholm, Sweden.

Swedish National Union of Students, SFS. (2013b). Utbildningens användbarhet. Sveriges förenade studentkårer om syftet med högre utbildning (The usability of education. The Swedish National Union of Students' view on the purpose of higher education). Globalt företagstryckeri, Stockholm, Sweden.

Swedish National Union of Students, SFS. (2015). Agenda Pedagogik - Alla fattar utom jag. Hur skapar vi förutsättningar för god undervisning? (Everybody understands except me. How do we create conditions for excellent teaching?) Stockholm. Retrieved from https://www.sfs.se/sites/default/files/agenda_pedagogik_ alla fattar_utom_jag.pdf. 2018-02-07.

Sword, $\bar{H}$. (2011). Archiving for the future: a longitudinal approach to evaluating a postgraduate certificate program. In L. Stefani (Ed.), Evaluating the effectiveness of academic development: principles and practice. New York: Routledge.

Troiano, H., \& Elias, M. (2014). University access and after: explaining the social composition of degree programmes and the contrasting expectations of students. Higher Education, 67(5), 637-654.

Trowler, P. (1998). Academics responding to change. Ballmore: Open university Press.

Trowler, P., \& Bamber, R. (2005). Compulsory higher education teacher training: joined-up policies, institutional architectures and enhancement cultures. International Journal for Academic Development, 10(2), 79-93.

Young, M. (2007). Bringing knowledge back in: from social constructivism to social realism in the sociology of education. City: Routledge. 